\title{
Ranitidine induced bronchospasm during spinal anaesthesia
}

\author{
T Bansal ${ }^{*}$, S Hooda ${ }^{2}, R$ Jaiswal ${ }^{3}$ \\ Assistant Professor ${ }^{1}$, Senior Professor ${ }^{2}$, Professor ${ }^{3}$, Department of Anaesthesiology and Critical Care, \\ University of Health Sciences, Rohtak-124001 Haryana, India.
}

*Corresponding author: aggarwalteenu@ rediffmail.com

\begin{abstract}
Bronchospasm although is a rare event under spinal anaesthesia, has the potential to become an anaesthetic disaster if not recognized and managed properly. Ranitidine induced bronchospasm is a rare event in anaesthesia practice. We hereby report a case of successful management of bronchospasm under spinal anaesthesia in a 55 year female posted for femoropopliteal bypass grafting because of ranitidine administration.
\end{abstract}

Key words: ranitidine, bronchospasm, spinal anaesthesia

\section{Introduction}

Bronchospasm has the potential to become an anaesthetic disaster if it is not recognized. The incidence of bronchospasm is relatively higher with general anaesthesia, however is a rare event under spinal anaesthesia as there is no airway manipulation. Intraoperative bronchospasm under spinal anaesthesia may occur because of various causes like high level of sensory blockade, drug induced histamine release, parasympathomimetic stimulation (surgical stimulation), prior history of asthma, anaphylaxis or drugs with beta blocking activity. ${ }^{1}$ Ranitidine an $\mathrm{H}_{2}$ receptor antagonist has been associated with anaphylactic reactions. ${ }^{2} \mathrm{We}$ hereby report a case of bronchospasm under spinal anaesthesia in a 55 year female posted for femoropopliteal bypass grafting because of ranitidine administration.

\section{Case report}

55 year female having peripheral arterial disease was scheduled for emergency femoro-popliteal bypass grafting because of pain in lower limbs. She was a chronic smoker. There was no previous history of bronchial allergy and any other respiratory complaint. She had no significant medical and surgical history. Blood pressure was $130 / 80 \mathrm{mmHg}$ and pulse was $90 / \mathrm{min}$. Complete haemogram, bleeding time, clotting time, urine examination, blood urea, blood sugar, chest $\mathrm{X}$ ray and electrocardiography were normal. Regional anaesthesia (spinal along with epidural) was planned for the procedure. In the operating room, standard monitors were attached. Epidural catheter was placed under aseptic precautions at $\mathrm{L}_{2}-$
$\mathrm{L}_{3}$ interspace. Lumbar puncture was done with $23 \mathrm{G}$ quincke needle at $\mathrm{L}_{3}-\mathrm{L}_{4}$ interspace. Clear CSF (cerebrospinal fluid) was obtained and $2.5 \mathrm{ml}$ of $0.5 \%$ hyperbaric bupivacaine with $25 \mu \mathrm{g}$ fentanyl was injected. Adequate sensory block was achieved upto $\mathrm{T}_{10}$. After 3 hours, patient complained of epigastric pain. Ranitidine $50 \mathrm{mg}$ was given intravenously. After 10 minutes, patient complained of shortness of breath. $\mathrm{SpO}_{2}$ was $91 \%$. Auscultation of the chest revealed bilateral rhonchi. Hydrocortisone $100 \mathrm{mg}$ was given intravenously and the patient was nebulized with levosalbutamol. Bronchospasm got relieved after 20 minutes.Her $\mathrm{SpO}_{2}$ became 99\%. Surgery lasted for 5 hours and postoperative course was uneventful. A provocation test was performed after 3 days with one tablet (150mg) ranitidine. Patient developed diffuse bronchospasm 3 hours after the drug administration which was treated with 100mg hydrocortisone intravenously and nebulisation with levosalbutamol. Patient was advised not to take ranitidine in the future.

\section{Discussion}

Ranitidine is commonly used as a preanaesthetic medication in addition to its conventional use in peptic ulcers and hyper secretory states. As compared to other $\mathrm{H}_{2}$ receptor blockers, it has lesser side effects. Development of bronchospasm after intake of ranitidine is an uncommon event. This compound is a substituted aminoalkyl furan without the imidazole nucleus present in other $\mathrm{H}_{2}$ receptor blockers. 
Mudaraddi et al reported a case of intraoperative bronchospasm in a patient who was scheduled for emergency caesarean section under spinal anaesthesia due to high level of sensory blockade. ${ }^{3}$ The principal function of the sympathetic (T2-T4) supply to the lung is bronchodilation. The stimulation of the parasympathetic nervous system is implicated in the pathogenesis of bronchospasm. A thoracic sympathetic blockade which is made by spinal anaesthesia might trigger bronchospasm by influencing the cholinergic ganglia of the lung and the pulmonary blood flow. This could not be the reason in our case as the level of sensory block was T10. As our patient was having sensory block upto T10, surgical stimulation was also ruled out. Also, patient had no prior history of asthma and was not on beta blockers.

Bronchospasm under spinal anaesthesia can be due to various drugs used. In our patient it might be due to ranitidine used for relief of epigastric pain. In bronchi, $\mathrm{H}_{1}$ and $\mathrm{H}_{2}$ receptors are present and both these play a role in causing bronchospasm. $\mathrm{H}_{1}$ receptors lead to bronchoconstriction and $\mathrm{H}_{2}$ receptors lead to bronchodilatation. $\mathrm{H}_{2}$ receptor blockade prevents the negative feedback of histamine on further mediator release. Ranitidine is an $\mathrm{H}_{2}$ receptor blocker and causes a rise in plasma histamine levels which can lead to bronchospasm. ${ }^{5}$ In addition; ranitidine is a substituted aminoalkyl furan. The furan nucleus present in it might be responsible for urticarial lesions also. ${ }^{6}$

To conclude ranitidine induced bronchospasm is a rare event in anaesthesia practice but when it occurs can become an anaesthetic disaster if not recognized and managed promptly.

\section{References}

1. Prabhakar H, Rath GP. Intraoperative bronchospasm under spinal analgesia. Middle East Journal of Anaesthesiology 2007; 19: 225-9. PMid:17511197

2. Lazaro M, Compaired JA, De la Hoz Bet al. Anaphylactic reaction to ranitidine. Allergy 1993;

48: 385-7.

http://dx.doi.org/10.1111/j.1398-

9995.1993.tb02412.x

\section{PMid:8368468}

3. Mudaraddi R, Kinthala S, Ramachandra UB. Intra-operative bronchospasm in a patient who was scheduled for emergency caesarean section under spinal anaesthesia. JCDR 2012; 6: 488-9.

4. Kawabata KM. Two cases of asthmatic attack which were caused by spinal anaesthesia. Masui 1996; 45(1): 102-6.

PMid:8965338

5. Parkin JV, Ackroyd EB, Glickman S, Hobsley M, Lorenz W. Release of histamine by H2-receptor antagonists. Lancet 1982; 320:938-9. http://dx.doi.org/10.1016/S0140-6736(82)90911-4

6. Aggarwal HK, Kalra OP, Jain VK, Mahajan SK. Ranitidine induced urticaria. The Indian Practitioner 1992; 45: 73-4. 